\title{
Mucin Expression and Corticosteroid Efficacy in Chronic Rhinosinusitis with Nasal Polyps
}

Peiró $\mathrm{T}^{1,2,5 \#}$, Milara $\mathrm{J}^{2,3,4,5 \# *}$, Armengot $\mathbf{M}^{6,7}$ and Cortijo $\mathrm{J}^{1,2,3,5}$

${ }^{1}$ Department of Pharmacology, Faculty of Medicine, University of Valencia, Spain

${ }^{2}$ Research Foundation of General Hospital of Valencia, Spain

${ }^{3}$ Clinical research unit (UIC), University General Hospital Consortium, Valencia, Spain

${ }^{4}$ Department of Biotechnology, Universidad Politécnica de Valencia, Spain

${ }^{5}$ CIBERES, Health Institute Carlos III, Valencia, Spain

${ }^{6}$ Rhinology Unit, University General Hospital Consortium, Valencia, Spain

${ }^{7}$ Department of Medicine, Faculty of Medicine, University of Valencia, Spain

\#authors Contributed equally

\begin{abstract}
Chronic rhinosinusitis with nasal polyps (CRSwNP) is an upper airway respiratory disease of the sinuses which may develop resistance to corticosteroid efficacy. Corticosteroids are the main therapy of this disease and as part of their anti-inflammatory activity they are known to exert an effect in mucin expression. This review aims to describe the current state-of-the-art knowledge regarding mucin expression in CRSwNP and its possible relation with corticosteroid efficacy, by highlighting the differential expression of membranetethered versus secreted mucins in different subsets of CRSwNP with an emphasis in corticosteroid non-responder patients. In addition, this review aims to suggest potential interactions between mucins and corticosteroids that could be addressed in future research to ascertain the role of mucins in the corticosteroid resistant mechanisms of this disease. In this sense, among the different mucins, we will highlight the membrane-tethered MUC1 and its potential role in corticosteroid-resistant CRSwNP, as it is currently considered an especially relevant mucin due to its anti-inflammatory properties.
\end{abstract}

Keywords: Mucins; Corticosteroids; Corticosteroid resistance; Chronic rhinosinusitis with nasal polyps; MUC1

\section{Introduction}

Inflammatory phenotypes in chronic rhinosinusitis with nasal polyps (crswnp) and their relation with corticosteroid resistance

CRSwNP is an inflammatory disease of the nose and paranasal sinuses characterized by polyp formation in the latter. The main symptoms of CRSwNP are nasal obstruction or discharge, which are usually accompanied by the presence of other symptoms such as facial pain or pressure and loss of smell. The chronic characteristic of this disease is evidenced by the persistence of these symptoms during 12 weeks or more without their complete resolution [1]. CRSwNP has been associated with different clinical factors, among which asthma and aspirin sensitivity are highlighted due to the estimates that point out that $\sim 10-15 \%$ of asthmatics and over $90 \%$ with aspirin intolerant asthma (AIA) suffer this disease [1]. This last subset of patients, known as Samter's or aspirin triad, suffer CRSwNP, aspirin sensitivity and asthma and are associated with a particularly persistent and therapyresistant form of the disease [1]. Moreover, corticosteroid resistant CRSwNP constitute an additional subset of patients that fail to respond to corticosteroids showing a limited clinical response, thus posing a challenge for research as currently their therapeutic options to control the disease only rely in undergoing sinus surgery.

Nasal polyps are formed by a pseudostratified ciliated epithelium with a thickened basal membrane, stromal edema, fibrotic foci, a sparse presence of vascularity, glands and innervations, and exhibit a high infiltration of different cell types such as eosinophils, lymphocytes, and plasma cells [2,3]. Despite eosinophils are historically considered the major cellular infiltrate and hallmark of CRSwNP and are regarded as a differential aspect from other types of CRS without polyps [4,5], it is important to highlight that some subsets of CRSwNP show relatively low eosinophilia with a predominant influx of other cell types. In this sense, nasal polyp mucosa inflammation exhibiting a high eosinophilic infiltration and orchestrated mainly by $\mathrm{TH} 2$ cytokines has been specifically associated with a majority of Caucasian CRSwNP $[3,6]$ while, in contrast, Asian polyps are less eosinophilic, more neutrophilic, and exhibit a Th1/17 cytokine pattern $[7,8]$. The relevance of the different eosinophilic and neutrophilic CRSwNP phenotypes has been highlighted recently, as they have been linked with a differential response to corticosteroids, the main treatment of this disease. While eosinophilic inflammation is generally considered sensitive to corticosteroid treatment, increased neutrophilia in nasal polyps has been related with a reduced response to corticosteroid therapy [9]. This differential response to corticosteroids depending on the eosinophilic or neutrophilic inflammatory phenotype shows a resemblance with that described in asthma [10], evidencing the close interrelationship between these diseases.

The accumulation of fibroblasts foci in CRSwNP has also been related with the limited clinical response to corticosteroid treatment, result of a relative resistance to the anti-proliferative and collagen deposition inhibitory effects of these drugs. In this sense, previous results have described the relation between the poor responses of nonresponder patients with the impaired sensitivity of fibroblasts to the effects of corticosteroids [11].

Our group is currently studying corticosteroid-resistant CRSwNP patients, among other phenotypes, in order to investigate the potential relationship between mucin expression and corticosteroid efficacy and

*Corresponding author: Javier Milara, Unidad de Investigación, Consorcio Hospital General Universitario, Avenida Tres Cruces s/n, E-46014 Valencia, Spain, Tel: +34 620231549; Fax: +34961972145; E-mail: xmilara@hotmail.com

Received December 31, 2013; Accepted January 20, 2014; Published February 01,2014

Citation: Peiró T, Milara J, Armengot M, Cortijo J (2014) Mucin Expression and Corticosteroid Efficacy in Chronic Rhinosinusitis with Nasal Polyps. J Steroids Hormon Sci S12: 007. doi:10.4172/2157-7536.S12-007

Copyright: (C) 2014 Peiró T, et al. This is an open-access article distributed unde the terms of the Creative Commons Attribution License, which permits unrestricted use, distribution, and reproduction in any medium, provided the original author and source are credited. 
establish potential common mechanisms. The following figure shows representative stained sections of nasal polyp from non-asthmatic and corticosteroid-resistant CRSwNP patients that support previous evidences describing the absence of eosinophilic infiltration (Figure 1B) and the presence of abundant fibrotic foci and extracellular matrix deposition (Figure 1D) in nasal polyps from corticosteroid nonresponder patients compared to non-asthmatic CRSwNP, which are mainly characterized by eosinophilic inflammation and the absence of fibroblasts (Figure 1A-1C).

\section{Membrane-tethered and secreted mucins and their expression in CRSwNP}

The fact that this inflammatory process of the nasal and paranasal sinus mucosa occurs at the interface with the external environment supports the evidences that suggest that this inflammatory response could result from an inappropriate or excessive immune response to foreign agents, such as bacteria, fungi, allergens or viruses $[1,12]$.

This continuous exposure of the upper airways to environmental particles and potential pathogens emphasizes the necessity of diverse fundamental defense mechanisms, such as mucociliary clearance, physical exclusion and the innate and adaptative immune responses, to protect the host by filtering, clearing and eliminating the potential dangers in order to prevent acute or chronic inflammatory processes [13].

The epithelial cell barrier, its motile cilia and the overlaying mucus layer are the main constituents of the mechanical barrier of the sinonasal mucosa and contribute to mucociliary transport as first line of defense. Mucins are widely known key components of the airway epithelial mucus layer that contribute to the protection of the epithelium from pathogens and irritants through their participation in

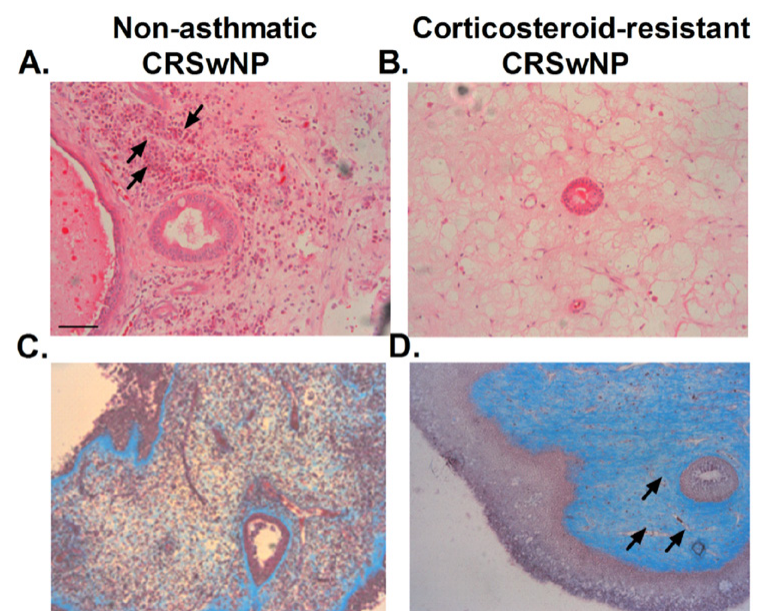

Figure 1: Nasal polyp sections showing submucosal glands from $(A, C)$ nonasthmatic and $(B, D)$ corticosteroid-resistant CSRwNP patients were stained with haematoxylin $(A, B)$ and Masson's trichrome stain (C,D). Haematoxylin stain differentiates the type of inflammatory cellular infiltrate in nasal polyps, distinguishing between: (A) major eosinophilic infiltrate (black arrows) in nonasthmatic CRSwNP patients compared to $(B)$ absence of eosinophilic infiltrate in corticosteroid-resistant CRSwNP patients. Masson's trichrome stain evidences the presence of extracellular matrix and collagen deposition (blue), distinguishing from cellular cytoplasm (pink) and nuclei (dark pink). Images show the differences in fibroblast and extracellular matrix abundance, between (C) non-asthmatic CRSwNP, with scarce presence of fibroblast foci, compared to (D) corticosteroid-resistant CRSwNP, with abundant presence of fibroblast foci and extracellular matrix deposition (black arrows). Representative images are shown. Scale bar $=50 \mu \mathrm{m}$. the mucociliary clearance mechanism [14]. However, recent increasing evidence suggests mucin are also involved in other less conventional roles of high interest, such as host defense against airway infection [15].

Mucins are heavy weight glycoproteins, produced by surface epithelium goblet cells and submucosal glands, characterized by an extensively glycosylated protein structure with variable number of amino acid tandem repeats, especially rich in serine, threonine and proline, that represent the potential sites for O-glycosilation. The number of human mucin genes identified up to the date is 22 , among which 16 are known to be expressed in the respiratory epithelium $[14,16]$. These mucins are classified in two groups, with different structural and functional properties, considering their secreted or membrane-tethered nature (Table 1 ).

Membrane-tethered mucins are transmembrane proteins anchored to the apical surface of mucosal epithelial cells, with a highly glycosylated $\mathrm{N}$-terminal domain in contact with the outside environment acting as a sensor receptor and a short cytoplasmic tail (CT) that enables its participation in intracellular signaling [14]. Therefore, these membrane-bound mucins not only modulate extracellular interactions on epithelial cell surfaces but also participate in intra-cellular signaling [17]. In contrast, secreted mucins are the most abundant glycoprotein component in mucus, being directly involved in mucus formation and responsible of its viscoelastic and gel-forming properties [14]. Secreted mucins lack a transmembrane domain, as they are secreted to the extracellular space, and their distinctive feature includes at least five important cysteine-rich domains [18]. However, their importance shouldn't be underestimated as recent publications highlight their essential role in airway defense [19].

Pathological conditions of the upper airways are thought to be a consequence of a dysfunctional capacity of the nasal epithelium to deal with pathogens, being incapable of controlling appropriate and regulated immune responses. As a consequence, the defects in the immune response and in the mechanical barrier defense mechanisms are considered to be related with the establishment of pathologies such as CRSwNP and the development of the characteristic clinical symptoms of these diseases [13]. Mucus hypersecretion in the upper airways, in the form of rhinorrea, is a common symptom of patients with nasal polyposis and is considered a hallmark of this disease [14].

Previous studies have described a differential mucin expression pattern in nasal polyps compared to healthy upper airway mucosa [20-22]. The mucins MUC1, 2, 3, 4, 5AC, 5B, 7, and 8 are known to be expressed in the epithelium of the human airway and focusing exclusively in nasal polyps, the expression of mucins MUC1, 2, 4, 5AC, 5B and 8 mRNA [20] and MUC16 [22] has been reported. Among these mucins, the membrane-bound mucin MUC4 and the secreted mucin $-5 \mathrm{AC}$ have been described as the major components of both submucosal glands and epithelial cells in nasal polyps [21].

In our current research to ascertain a potential relationship between mucin expression and corticosteroid efficacy, we have studied the expression of different secreted and membrane-tethered mucins in corticosteroid responder and non-responder CRSwNP groups of patients. Nasal polyps from all the CRSwNP patients included in our study were diagnosed according to the European Position Paper on Rhinosinusitis and Nasal Polyps 2012 guidelines [1] based on endoscopy and/or computerized tomography. All the patients showed extensive nasal polyps, which were classified with the following scoring system according to their size: 1 (small polyps in the middle meatus not reaching below the inferior border of the middle concha), 2 (polyps 
Citation: Peiró T, Milara J, Armengot M, Cortijo J (2014) Mucin Expression and Corticosteroid Efficacy in Chronic Rhinosinusitis with Nasal Polyps. J Steroids Hormon Sci S12: 007. doi:10.4172/2157-7536.S12-007

Page 3 of 10

\begin{tabular}{|c|c|c|c|c|}
\hline Mucin & Type & Location & Physiological \& pathological roles & Corticosteroid effect \\
\hline MUC1 & MT & $\begin{array}{l}\text { Lung and airways (lining } \\
\text { epithelial cells of the lung and } \\
\text { alveolar type II cells). } \\
\text { Normal nasal mucosa. } \\
\text { Nasal polyps. } \\
\text { Other: } \\
\text { Nearly all epithelium. } \\
\text { Hematopoietic cells. } \\
\text { Activated T cells } \\
\text { (lymphocytes, dendritic cells). } \\
\text { Sperm } \\
\text { Corneal endothelial cells. } \\
\text { Breast. } \\
\text { Pancreas. }\end{array}$ & $\begin{array}{l}\text { Responsible for viscoelastic nature of mucus. } \\
\text { Role as protective barrier against invading pathogens and } \\
\text { chemicals: Aids in mucociliary clearance of foreign bodies. } \\
\text { Provides defense to the upper and lower respiratory tracts. } \\
\text { Anti-inflammatory role during airway infection, controlling } \\
\text { the resolution of inflammation through the inhibition of TLR } \\
\text { signaling. } \\
\text { Associated with epithelial cell differentiation (in stomach, } \\
\text { pancreas, lung, trachea, kidney, salivary and mammary } \\
\text { glands and the female reproductive tract). } \\
\text { Tumor-associated molecule (frequent over expression and } \\
\text { aberrant glycosilation in many cancers including, breast, } \\
\text { pancreas, colon, lung and endometrial cancer). } \\
\text { Promotes cancer metastasis and tumorigenesis. } \\
\text { Functions of the different MUC1 segments: } \\
\text { - Ectodomain (anti-adhesive, pro-adhesive, hydration and } \\
\text { lubrication of cell surfaces, ERBB signaling). } \\
\text { - Cytoplasmic tail (signal transduction, and transcriptional } \\
\text { regulation; participation in cell growth and proliferation } \\
\text { mechanisms, cell protection from apoptosis). }\end{array}$ & $\begin{array}{l}\text { YES } \\
\text { In vitro studies: } \\
\text { Dexamethasone increases MUC1 expression } \\
\text { in cancer cell lines [60,61]. Dexamethasone } \\
\text { upregulates MUC1 expression in human corneal } \\
\text { epithelial cells [62]. } \\
\text { In vivo studies: } \\
\text { Corticosteroid therapy increases MUC1 } \\
\text { expression in nasal polyps [64]. }\end{array}$ \\
\hline MUC2 & $S$ & $\begin{array}{l}\text { Lung and airways. } \\
\text { Normal nasal mucosa. } \\
\text { Nasal polyps. } \\
\text { Other: } \\
\text { Intestines (Jejunum, ileum, } \\
\text { colon) }\end{array}$ & $\begin{array}{l}\text { Major mucin secreted in the large intestine. } \\
\text { Important role in: host innate defense, regulation of secretion, } \\
\text { absorption processes, maintaining colonization resistance } \\
\text { that contribute in maintaining the integrity of the protective } \\
\text { mucus barrier in the large intestine [78]. } \\
\text { The expression of MUC2 correlates with the activity of } \\
\text { diseases, such as ulcerative colitis and Crohn's diseases } \\
\text { [78]. }\end{array}$ & $\begin{array}{l}\text { YES } \\
\text { In vitro studies: } \\
\text { Budesonide inhibits the induction of MUC2 by } \\
\text { inflammatory mediators in airway epithelial cells } \\
{[58,59] .}\end{array}$ \\
\hline MUC3 & MT & $\begin{array}{l}\text { Gastrointestinal epithelium (co- } \\
\text { lon, small intestine, gall bladder) }\end{array}$ & $\begin{array}{l}\text { Major mucin secreted in the large intestine. } \\
\text { Important role in: host innate defense, regulation of secretion, } \\
\text { absorption processes, maintaining colonization resistance } \\
\text { that contribute in maintaining the integrity of the protective } \\
\text { mucus barrier in the large intestine [78]. } \\
\text { The expression of MUC3 correlates with the activity of diseases, } \\
\text { such as ulcerative colitis and Crohn's diseases [78]. }\end{array}$ & $\begin{array}{l}\text { YES } \\
\text { In vitro studies: } \\
\text { Steroids upregulate MUC3 expression in cultured } \\
\text { breast cancer cells [79]. }\end{array}$ \\
\hline MUC4 & MT & $\begin{array}{l}\text { Lung and airway surface epithe- } \\
\text { lial cells. } \\
\text { Normal nasal mucosa. } \\
\text { Nasal polyps. } \\
\text { Other: } \\
\text { Epithelium (eye, oral cavity, } \\
\text { lacrimal glands, salivary gland, } \\
\text { cervix, prostate gland, stomach, } \\
\text { colon and mammary gland). }\end{array}$ & $\begin{array}{l}\text { Responsible for viscoelastic nature of mucus. } \\
\text { Role as protective barrier against invading pathogens and } \\
\text { chemicals: Aids in mucociliary clearance of foreign bodies. } \\
\text { Provides defense to the upper and lower respiratory tracts. } \\
\text { Implicated in tumor progression by inducing increased cell } \\
\text { growth, proliferation and survival. } \\
\text { Aberrant expression in ovarian tumors and premalignant and } \\
\text { malignant pancreatic lesions. Frequently overexpressed lung, } \\
\text { breast and colon cancers. } \\
\text { Functions of the different MUC4 segments: } \\
\text {-Ectodomain (anti-adhesive, hydration and lubrication of cell } \\
\text { surfaces, ERBB signaling). }\end{array}$ & $\begin{array}{l}\text { YES } \\
\text { In vitro studies: } \\
\text { Dexamethasone inhibits MUC4 expression in nasal } \\
\text { polyps [22]. } \\
\text { Dexamethasone downregulates MUC4 expression } \\
\text { in human corneal epithelial cells [62]. Inhibitory } \\
\text { effect of corticosteroids in MUC4 increased mRNA } \\
\text { expression in nasal polyps [63]. } \\
\text { In vivo studies: } \\
\text { Corticosteroid therapy increases MUC4 expression } \\
\text { in nasal polyps [64]. }\end{array}$ \\
\hline MUC5AC & S & $\begin{array}{l}\text { Lung and airway epithelium } \\
\text { (goblet cells) } \\
\text { Normal nasal mucosa. } \\
\text { Nasal polyps. } \\
\text { Other: } \\
\text { Eyes. } \\
\text { Stomach. }\end{array}$ & $\begin{array}{l}\text { Major gel-forming mucin in the respiratory tract. } \\
\text { Responsible for viscoelastic nature of mucus. } \\
\text { Protection and stabilization of the ciliated surface. } \\
\text { Role as protective barrier against invading pathogens and } \\
\text { chemicals: Aids in mucociliary clearance of foreign bodies. } \\
\text { Provides defense to the upper and lower respiratory tracts. } \\
\text { Contribute to the defensive barrier function and the rheology } \\
\text { of the airways mucus. } \\
\text { Marker for goblet cell metaplasia. } \\
\text { Associated with respiratory diseases, mainly with asthma. }\end{array}$ & $\begin{array}{l}\text { YES } \\
\text { In vitro studies: Dexamethasone decreases } \\
\text { MUC5AC expression in both human epithelial cell } \\
\text { lines [55,56,57] and in primary bronchial epithelial } \\
\text { cells [57] and in rat primary airway epithelial cells } \\
\text { [56]. } \\
\text { Budesonide inhibits the induction of MUC5AC by } \\
\text { inflammatory mediators in airway epithelial cells } \\
\text { [58,59]. } \\
\text { In vivo studies: } \\
\text { Corticosteroids decrease secreted mucin MU- } \\
\text { C5AC expression in nasal polyps [64] }\end{array}$ \\
\hline
\end{tabular}


Citation: Peiró T, Milara J, Armengot M, Cortijo J (2014) Mucin Expression and Corticosteroid Efficacy in Chronic Rhinosinusitis with Nasal Polyps. J Steroids Hormon Sci S12: 007. doi:10.4172/2157-7536.S12-007

Page 4 of 10

\begin{tabular}{|c|c|c|c|c|}
\hline MUC5B & $S$ & $\begin{array}{l}\text { Lung and airway epithelium } \\
\text { (submucosal glands) } \\
\text { Normal nasal mucosa. } \\
\text { Nasal polyps. } \\
\text { Other: } \\
\text { Salivary glands. } \\
\text { Submandibular glands. }\end{array}$ & $\begin{array}{l}\text { Major gel-forming mucin in the respiratory tract. } \\
\text { Responsible for viscoelastic nature of mucus. } \\
\text { Protection and stabilization of the ciliated surface. } \\
\text { Role as protective barrier against invading pathogens and } \\
\text { chemicals: Aids in mucociliary clearance of foreign bodies. } \\
\text { Provide defense to the upper and lower respiratory tracts. } \\
\text { Contributes to the defensive barrier function and the rheology } \\
\text { of the airways mucus. } \\
\text { Associated with respiratory diseases, mainly with COPD. } \\
\text { Interaction between MUC5B and different salivary pro- } \\
\text { teins (important in the maintenance of oral physiology by: } \\
\text { enhanced physical protection, enhanced enamel integrity, } \\
\text { enhanced non-immune host defense). }\end{array}$ & $\begin{array}{l}\text { YES } \\
\text { In vivo studies: } \\
\text { Corticosteroids decrease secreted mucin MUC5B } \\
\text { expression in nasal polyps [64]. }\end{array}$ \\
\hline MUC6 & S & $\begin{array}{l}\text { Stomach, ileum, gall bladder. } \\
\text { Breast. }\end{array}$ & $\begin{array}{l}\text { MUC6 is expressed in normal, benign and in malignant } \\
\text { breast cancer [79]. }\end{array}$ & $\begin{array}{l}\text { YES } \\
\text { In vitro studies: } \\
\text { Steroids upregulate MUC6 expression in cultured } \\
\text { breast cancer cells [79]. }\end{array}$ \\
\hline MUC7 & $S$ & $\begin{array}{l}\text { Lung and airways. } \\
\text { Normal nasal mucosa. } \\
\text { Nasal polyps. } \\
\text { Other: } \\
\text { Salivary glands. Sublingual and } \\
\text { submandibular glands. } \\
\text { Lacrimal gland acini. }\end{array}$ & $\begin{array}{l}\text { Secreted but not gel-forming mucin. } \\
\text { Interaction between mucins and different salivary proteins are } \\
\text { important in the maintenance of oral physiology (enhanced } \\
\text { physical protection, enhanced enamel integrity, enhanced } \\
\text { non-immune host defense). }\end{array}$ & Unknown. \\
\hline MUC8 & S & $\begin{array}{l}\text { Lung and airways. } \\
\text { Normal nasal mucosa. } \\
\text { Nasal polyps. }\end{array}$ & $\begin{array}{l}\text { MUC8 overexpression in nasal polyps. } \\
\text { Upregulation of MUC8 mRNA expression by inflammatory } \\
\text { mediators [80]. } \\
\text { MUC8 as a ciliated cell marker in human nasal epithelium } \\
\text { [81]. }\end{array}$ & $\begin{array}{l}\text { YES } \\
\text { In vitro studies: } \\
\text { Dexamethasone suppressed lipopolysaccharide- } \\
\text { induced MUC8 mRNA levels in cultured human } \\
\text { nasal epithelial cells [82]. }\end{array}$ \\
\hline MUC9 & $\begin{array}{l}\text { S and } \\
\text { MT }\end{array}$ & Ovaries. Fallopian tubes & $\begin{array}{l}\text { MUC9 is expressed in malignant epithelial ovarian tumors } \\
\text { [83]. } \\
\text { MUC9 or oviductal glycoprotein (OVGP1) is present in serum } \\
\text { of women with ovarian cancer and has been described as } \\
\text { possible serum marker for the detection of ovarian cancer } \\
\text { [83]. }\end{array}$ & Unknown. \\
\hline MUC10 & & Submandibular mucin. & Salivary mucin. & Unknown \\
\hline MUC11 & MT & $\begin{array}{l}\text { Lung } \\
\text { Other: } \\
\text { Colon } \\
\text { Reproductive tract. }\end{array}$ & & Unknown \\
\hline MUC12 & MT & $\begin{array}{l}\text { Stomach, colon, pancreas, } \\
\text { prostate, uterus. }\end{array}$ & & Unknown \\
\hline MUC13 & MT & $\begin{array}{l}\text { Lung and airways. } \\
\text { Other: } \\
\text { Colon, trachea, kidney, small } \\
\text { intestine, conjunctival epithelium. }\end{array}$ & $\begin{array}{l}\text { Aberrantly expressed in gastric, colorectal, ovarian [84], } \\
\text { pancreatic, lung ovarian carcinomas. } \\
\text { MUC13 overexpression increases cell growth, colony } \\
\text { formation, cell migration, and invasion [85]. }\end{array}$ & Unknown \\
\hline MUC15 & MT & $\begin{array}{l}\text { Lung and airways. } \\
\text { Other [86]: Colon, small intes- } \\
\text { tine, prostate, placenta, salivary } \\
\text { gland, thyroid gland, moder- } \\
\text { ately in the kidney, conjunctival } \\
\text { epithelium. }\end{array}$ & $\begin{array}{l}\text { Aberrant expression of MUC15 correlates with development } \\
\text { of colorectal adenocarcinoma [87]. } \\
\text { MUC15 potential marker of malignancy and prognosis in } \\
\text { papillary thyroid carcinoma [88]. }\end{array}$ & Unknown \\
\hline MUC16 & MT & $\begin{array}{l}\text { Lung and airways surface epithe- } \\
\text { lial cells. } \\
\text { Nasal polyps. } \\
\text { Other: } \\
\text { Epithelium of the ocular surface, } \\
\text { reproductive organs and the } \\
\text { mesothelium lining body cavities } \\
\text { (pleural, peritoneal, and pelvic } \\
\text { cavities). Conjunctival epithelium }\end{array}$ & $\begin{array}{l}\text { Role as protective barrier against invading pathogens and } \\
\text { chemicals. } \\
\text { Overexpressed in ovarian and endometrial cancer. } \\
\text { Well-known serum marker for ovarian cancer (CA 125). }\end{array}$ & $\begin{array}{l}\text { YES } \\
\text { In vitro studies: } \\
\text { Dexamethasone upregulates MUC16 expression } \\
\text { in vitro in human corneal epithelial cells [62]. } \\
\text { Dexamethasone increases MUC16 expression at } \\
\text { both the mRNA and protein levels in nasal polyp } \\
\text { epithelial cells [22]. }\end{array}$ \\
\hline
\end{tabular}


Citation: Peiró T, Milara J, Armengot M, Cortijo J (2014) Mucin Expression and Corticosteroid Efficacy in Chronic Rhinosinusitis with Nasal Polyps. J Steroids Hormon Sci S12: 007. doi:10.4172/2157-7536.S12-007

Page 5 of 10

\begin{tabular}{|c|c|c|c|c|}
\hline MUC17 & MT & $\begin{array}{l}\text { Gastrointestinal tract (duode- } \\
\text { num, colon, stomach) Conjuncti- } \\
\text { val epithelium }\end{array}$ & $\begin{array}{l}\text { MUC17 has a role in protecting the intestinal mucosa against } \\
\text { luminal pathogens [89]. } \\
\text { MUC17 is expressed in select pancreatic and colon cancer } \\
\text { cell lines and in intestinal absorptive cells [90]. } \\
\text { Aberrant overexpression of MUC17 is correlated with } \\
\text { pancreatic ductal adenocarcinomas [91]. }\end{array}$ & Unknown. \\
\hline MUC18 & MT & $\begin{array}{l}\text { Lung and airways. } \\
\text { Other: } \\
\text { Breast. }\end{array}$ & $\begin{array}{l}\text { MUC18 has been shown to promote metastasis in several } \\
\text { tumors, such as breast cancer [92] and melanoma [93] by } \\
\text { increasing their motility, invasiveness and tumorigenesis. } \\
\text { MUC18 amplifies lung inflammation during bacterial infection } \\
{[94,95] \text {. }}\end{array}$ & Unknown. \\
\hline MUC19 & $S$ & $\begin{array}{l}\text { Lung and airways (Trachea) } \\
\text { Other: } \\
\text { Salivary gland. }\end{array}$ & Major salivary glandular mucin. & Unknown. \\
\hline MUC20 & MT & $\begin{array}{l}\text { Lung and airways. } \\
\text { Other: } \\
\text { Placenta, colon, prostate, liver. }\end{array}$ & Upregulated in renal injuries [96]. & Unknown. \\
\hline MUC21 & MT & Lung and airways. & $\begin{array}{l}\text { MUC21 modulates cell adhesion [97]. } \\
\text { Marker for lung adenocarcinomas. }\end{array}$ & Unknown. \\
\hline MUC22 & MT & Lung and airways. & & Unknown. \\
\hline
\end{tabular}

*MT: Membrane-tethered mucin; S: secreted mucin.

${ }^{*}$ General data in the table reviewed previously in several mucin reviews $[14,15,18,21,73,98,99]$.

Table 1: Mucins, their characteristics and modulation by corticosteroids.

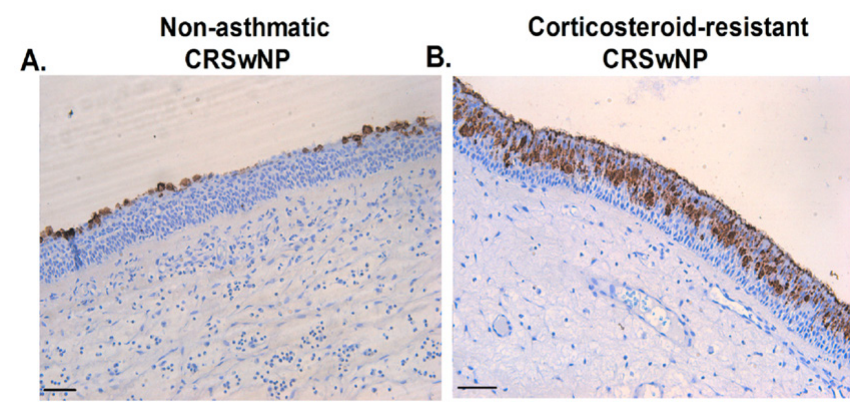

Figure 2: Nasal polyp sections showing epithelium from (A) non-asthmatic and $(B)$ corticosteroid-resistant CSRwNP patients were immunostained for MUC5AC (brown) and counterstained with haematoxylin. Representative Immunohistochemistry images are shown. Scale bar $=50 \mu \mathrm{m}$.

reaching below the lower border of the middle turbinate), 3 (large polyps reaching the lower border of the inferior turbinate or polyps medial to the middle concha), large polyps causing almost complete congestion/obstruction of the inferior meatus). The different subsets of patients showed similar bilateral nasal polyp endoscopic scores ( $\sim 5.5$ score). All the patients received oral corticosteroid treatment at the moment of recruitment (deflazacort at $1 \mathrm{mg} / \mathrm{kg} /$ day during 8 days followed by $0.5 \mathrm{mg} / \mathrm{kg} /$ day during other 7 days) and corticosteroid resistance was evaluated at day 15 after corticosteroid therapy. Those patients unable to reduce more than 1 nasal polyp endoscopic score after oral corticosteroid treatment were considered resistant, thus were classified in the corticosteroid-resistant group. Representative MUC5AC immunostaining in nasal polyp sections of non-asthmatic and corticosteroid-resistant CRSwNP patients are shown in Figure 2. These images evidence an increased expression of the secreted mucin MUC5AC in corticosteroid-resistant CRSwNP patients (Figure 2B) compared to CRSwNP responder patients (Figure 2A).

\section{Corticosteroid efficacy in chronic rhinosinusitis with nasal polyposis (CRSwNP)}

Corticosteroids are the drugs of choice as main treatment for CRSwNP, based on their strong anti-inflammatory activity [1]. Among these, topical intra-nasal corticosteroids constitute the first option due to their effects in maintaining clinical control of the symptoms [23], in reducing the size and extent of nasal polyps [24-27] and the number of recurrence episodes after polyp removal $[28,29]$, thus being considered the most effective drug available. However topical corticosteroids are not always effective, as complete remission of the polyps with this treatment is only achieved in $60-80 \%$ of cases [30], leading to the use of systemic corticosteroids as the next available option. Systemic corticosteroids are accepted as an effective therapy in treating severe CRSwNP, demonstrated in a 2 -week course of oral corticosteroids study where they reduced significantly the symptoms and polyp size [31]. Nevertheless, there is still a subset of patients that show resistance to the effects of corticosteroids due to cellular mechanistic resistance to this drug. In these cases, sinus surgery is the only available option in order to control the disease.

The mechanisms of action of corticosteroids in CRSwNP have been previously reviewed in the literature $[32,33]$. Corticosteroid's mechanisms involve corticosteroid receptors, which have been described to be present in all the nasal cell types with greatest numbers in epithelial cells, submucosal glands and leukocytes [34]. These receptors are located in the cellular cytoplasm and they bind corticosteroids with high affinity [35]. The resultant steroid-receptor complex translocates to the nucleus of the cell where it promotes or inhibits gene transcription by diverse mechanisms, such as transactivation or transrepression [36]. Transactivation involves the binding of the complex to DNA sequences known as glucocorticoid response elements (GRE), which are found in the promoter regions of corticosteroid regulated genes, and results in the stimulation of anti-inflammatory molecule synthesis. However, their main antiinflammatory effect is the transrepressor effect, or the influence 
of corticosteroids in inactivating inflammatory gene transcription without the direct interaction with DNA. This effect is mediated by the bonding of this complex to transcription factors, such as the nuclear factor kappa beta (NF-k $\beta$ ) or activator protein-1 (AP-1), which results in the blockage of the transcription of pro-inflammatory citoquines, chemokines, adhesion molecules and inflammatory enzymes induced by these transcription factors [37-39]. Additionally, corticosteroids have also been described to affect histone acetylation through different mechanisms. For instance, corticosteroid's interaction with diverse co repressor molecules attenuating NF-k $\beta$ has an effect reversing histone acetylation and chromatin remodeling [40]. Moreover, activated corticosteroids recruit histone deacetylase (HDAC) 2 contributing to the suppression of multiple activated inflammatory genes [41].

The most commonly described corticosteroid-resistance mechanisms in CRSwNP have been related either with the ratio between corticosteroid receptor isoforms or with the action of transcription factors. Among the different corticosteroid receptor isoforms, $\alpha$ and $\beta$ are known as the two principal isoforms. The active isoform $\alpha$ forms a complex with the corticosteroid and interacts with the GRE elements affecting transcription mechanisms. In the other hand, corticosteroid receptor $\beta$ isoform is considered an inhibitor of corticosteroids as it is able to bind the GRE element on its own, blocking competitively the binding of the corticosteroid-receptor a complex to DNA, but is unable to exert an effect in gene expression $[42,43]$. Additionally, this isoform $\beta$ is also capable of binding isoform $\alpha$, creating a non active complex.

Several molecular mechanisms have been related with steroid resistance in CRSwNP, with close similarities to those mechanisms described in asthma (Table 2). Both of these corticosteroid receptor isoforms play a key role in corticosteroid resistance in CRSwNP, either by the increase of $\beta$ isoform, the decrease of $\alpha$ isoform or the imbalance of the ratio between these two isoforms [44]. In fact, several studies have described increased expression of isoform $\beta$ in CRSwNP patients compared to controls $[45,46]$. In addition, other studies reported a decreased expression of isoform $\alpha$ in CRSwNP compared to controls [47].

Other corticosteroid resistance mechanisms described in CRSwNP involve the direct inhibition of the bonding between the corticosteroid and the receptor by the action of transcription factors, such as NF-K $\beta$ or AP-1. Some studies have described NF-K $\beta$ activation and expression in CRSwNP and its relation with a worse response to corticosteroid treatment [48-50]. Other possible molecular mechanisms, which have

\begin{tabular}{l} 
- Corticosteroid receptor isoforms: \\
- Decreased corticosteroid receptor $\alpha$ isoform. \\
- Increased corticosteroid receptor $\beta$ isoform. \\
- Imbalance of the ratio between these two corticosteroid receptor isoforms. \\
- Increased expression of pro-inflammatory transcription factors, such as: \\
\hline - Nuclear factor kappa beta (NF-k $\beta$ ) \\
\hline - Activator protein-1 (AP-1) \\
- Corticosteroid receptor modifications: Increased phosphorylation of residues \\
decreases nuclear translocation capacity. \\
GRa phosphorylation at Ser ${ }^{226}$ contributes to steroid resistance by preventing \\
nuclear traslocation. This residue has been described to be phosphorylated by: \\
- Activation of p38 mitogen activated map kinase (p38MAPK). \\
- Increase in extracellular signal-regulated kinase (ERK). \\
- Increase in c-Jun N-terminal kinase (JNK) \\
- Decrease in MKP1. \\
- Defect in histone acetylation.
\end{tabular}

Table 2: Corticosteroid resistance molecular mechanisms in chronic rhinosinusitis with nasal polyposis (CRSwNP). Similarities with asthma [41]. been described to induce resistance in corticosteroid insensitive or severe asthma, result from the phosphorylation of specific residues of the corticosteroid-receptor a by several kinases. This modifications in the corticosteroid-receptor impair its binding capacity, stability and translocation to the nucleus [51]. Different kinases, such as p38 mitogen activated map kinase (p38MAPK) and others (Table 2), have been described to phosphorylate corticosteroid receptors in asthma, thus inhibiting their nuclear translocation [41,52]. Moreover, microbial superantigens, such as staphylococcal enterotoxin $B$, have been described to induce corticosteroid resistance through activation of extracellular signal-regulated kinase (ERK) pathways which leads to corticosteroid receptor phosphorylation at $\mathrm{Ser}^{226}$ [53]. This is especially relevant in the study of corticosteroid resistance in CRSwNP, as the surface of nasal polyps is colonized by multiple pathogenic bacterias that contribute to the inflammatory process through their superantigens and correlate with disease severity $[1,54]$.

\section{Mucin expression and corticosteroid efficacy in chronic rhinosinusitis with nasal polyps (CRSwNP)}

There are various in vitro studies in the literature that have described the effects of corticosteroids in mucin expression in the airway epithelium (Table 1). These studies mainly focused on secreted mucins although, in the last years, the importance of membrane-bound mucins in airway disease such as CRSwNP is gaining considerable relevance [22].

The corticosteroid dexamethasone has been described to decrease MUC5AC expression in human epithelial cell lines and in primary bronchial epithelial cells [55-57]. Moreover, budesonide has been described to inhibit the induction of major-gel forming mucins by inflammatory mediators in airway epithelial cells $[58,59]$.

Regarding membrane-bound mucins, dexamethasone has been described to affect MUC1 by increasing its expression in cancer cell lines $[60,61]$. Additionally, this corticosteroid has been described to upregulate MUC1 and MUC16 and downregulate MUC4 expression in vitro in human corneal epithelial cells [62].

Few studies have evaluated the effects of corticosteroids in the expression of membrane-tethered mucins in nasal polyps and their potential mechanistic interactions. A recent study described an increase in MUC16 expression at both the mRNA and protein levels in nasal polyp epithelial cells induced by dexamethasone, but no significant effect in MUC4 expression [22]. On the other hand, another previous study described an increased expression of MUC4 in nasal polyps and the inhibitory effect of corticosteroids' in MUC4 mRNA [63].

However, more relevantly, an in vivo study evaluated the effects of these drugs in patients with nasal polyps after a course of two weeks of oral corticosteroids and these drugs were described to exert an effect in mucin expression in human nasal polyp epithelium [64]. In this study, corticosteroid therapy was described to increase membranetethered mucins (MUC1 and MUC4) and decrease secreted mucins (MUC5AC and MUC5B) expression in nasal polyps, thus evidencing a differential regulatory effect of corticosteroid therapy in mucin expression depending on the nature of the mucin. These results would reinforce the idea that suggests that corticosteroids could be considered a beneficial therapy for mucus hypersecretion in this disease. As the authors point out, the corticosteroid-induced down-regulation of the levels of secreted mucins could result in a decrease of mucus hypersecretion and, in contrast, the up-regulation of membranetethered mucins could be related to their participation in epithelial 
repairing and remodeling processes. However, this study highlighted that AIA patients would require a special consideration as they showed a trend of resistance to this treatment. In fact, future research in corticosteroid resistance mechanisms is necessary to understand the particularly complex situation of therapy-resistance in AIA and corticosteroid non responder patients.

Our group has explored the expression of both membranetethered and secreted mucins in different cohorts of CRSwNP patients, which were selected according to relevant clinical factors that have been associated to this disease. In this sense, we have distinguished the following phenotypes: non-asthmatic CRSwNP, aspirin-tolerant asthmatic CRSwNP, aspirin-intolerant asthmatic CRSwNP and corticosteroid-resistant CRSwNP patients. Our results [65] (data not shown) evidence a down-regulation in the expression of MUC1, MUC4 and MUC16 in asthmatic, AIA and corticosteroid resistant CRSwNP patients compared to non-asmathic CRSwNP patients, which was most evident in the corticosteroid resistant group. In contrast, the expression of secreted mucins MUC5AC and MUC5B was increased in the corticosteroid resistant CRSwNP group, as shown previously in Figure 2. These results would evidence the failure of the corticosteroid's mechanisms to control clinical symptoms of this disease, particularly mucus hypersecretion, in corticosteroid-resistant CRSwNP patients.

The significance of these results is highlighted as they evidence an opposite pattern of mucin expression in the groups of patients studied, especially in corticosteroid-resistant patients, than that described previously in the literature due to the effects of these drugs. These results could point out towards a clinical implication of mucins in corticosteroid non-responder patients and provide a model to study the potential participation of mucins in the corticosteroid resistant mechanisms in CRSwNP due to a possible interaction between mucins and corticosteroids or their receptors.

During the last years there has been an increasing awareness of the importance of membrane-tethered mucin expression in different diseases. Focusing particularly in respiratory diseases, their expression has been linked to protective functions against different inflammatory or infectious agents [15], thus research in mucins has been directed towards investigating their potential anti-inflammatory benefits. Both their presence at the cell surface, conferring them a high accessibility, and their interaction with multiple proteins, conferring them an ability to regulate different signaling pathways, underline their biological significance and their potential implication in therapeutic strategies.

Among the different membrane-tethered mucins, MUC1 stands out as an anti-inflammatory molecule that has potential clinical applications. MUC1 has been extensively linked with intracellular signal transduction in cancer cells [66] however, it is MUC1's antiinflammatory role in the airways [67] which could imply a potential key role of this mucin in CRSwNP.

The anti-inflammatory role performed by MUC1 in the airways is evidenced by its participation in defense during airway infection, by inhibiting toll like receptor (TLR) signaling triggered by bacteria and virus [67-71]. The anti-inflammatory effect of MUC1 on TLR has been described to be mediated through its cytoplasmic MUC1CT component $[69,71]$. This is especially relevant in the study of CRSwNP, as the surface of nasal polyps is colonized by multiple pathogenic bacteria that, by either forming biofilms or through their superantigens, contribute to the inflammatory process and correlate with disease severity $[1,54]$.

MUC1 is located on the apical surface of mucosal epithelial cells and hematopoietic cells [72], where it acts as a sensor receptor able to participate in cellular signaling due to its characteristic structure [17]. As a member of the membrane-tethered mucin family, MUC1 is composed by three distinct subunits: a large heavily glycosylated extracellular ectodomain, a single-pass transmembrane region, and an intracellular cytoplasmic tail (CT) that contains several evolutionally conserved tyrosines (Figure 3). The phosphorylation of these tyrosine residues mediates the binding of different kinases and adapter proteins and modulates multiple intracellular signals [67].

As mentioned earlier, the increasing relevance of membrane-bound mucins is due to their ability to interact with multiple and different extracellular and intracellular proteins which constitute a large and diverse family of different proteins, known as mucin-interacting proteins [73]. Among these, the group of proteins that interact with MUC1-CT are the best characterized and, due to their diversity, MUC1-CT is known to be able to unchain multiple downstream signaling events [74].

In addition to the interaction of MUC1-CT with different proteins that act as signal transducers, MUC1-CT has been described to translocate to the nucleus of the cell where it mediates different biological responses. As an example, a previous study has described the interaction between MUC1-CT and the estrogen receptor (ER) a, forming a MUC1-CT-ER $\alpha$ transcription complex that translocates to the nucleus [75]. In addition, another transcription complex involving MUC1-CT, $\beta$-catenin-MUC1-CT, has been described to modulate morphogenesis $[76,77]$. In both cases, the formation of these transcription complexes has been described to exert a protective role against degradation $[75,76]$.

Our data concerning the decreased expression of MUC1 in corticosteroid resistant CRSwNP patients [65] has guided our current research to focus in evaluating the mechanistic link between MUC1 and corticosteroid's anti-inflammatory efficacy. The anti-inflammatory properties of MUC1 in airway inflammation are known to be related with its capacity to inhibit several TLR [69], particularly through MyD88 recruitment [71]. This inhibition prevents various downstream signaling cascades which would lead to the transcription of different pro-inflammatory genes (Figure 4). In addition, as described previously, MUC1 is also known due to its capacity to mediate the translocation of several transcription factors to the nucleus, where these exert their

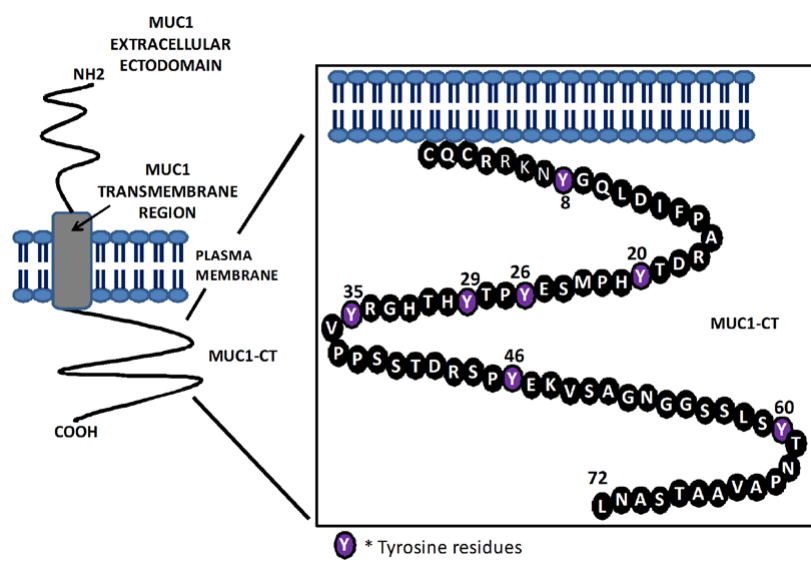

Figure 3: MUC1 structure. The membrane-tethered mucin MUC1 is composed by three distinct subunits: a large heavily glycosylated extracellular ectodomain a single pass transmembrane region, and an intracellular cytoplasmic tail (CT) that contains several evolutionally conserved tyrosines $(\mathrm{Y})$ 
Citation: Peiró T, Milara J, Armengot M, Cortijo J (2014) Mucin Expression and Corticosteroid Efficacy in Chronic Rhinosinusitis with Nasal Polyps. J Steroids Hormon Sci S12: 007. doi:10.4172/2157-7536.S12-007

Page 8 of 10

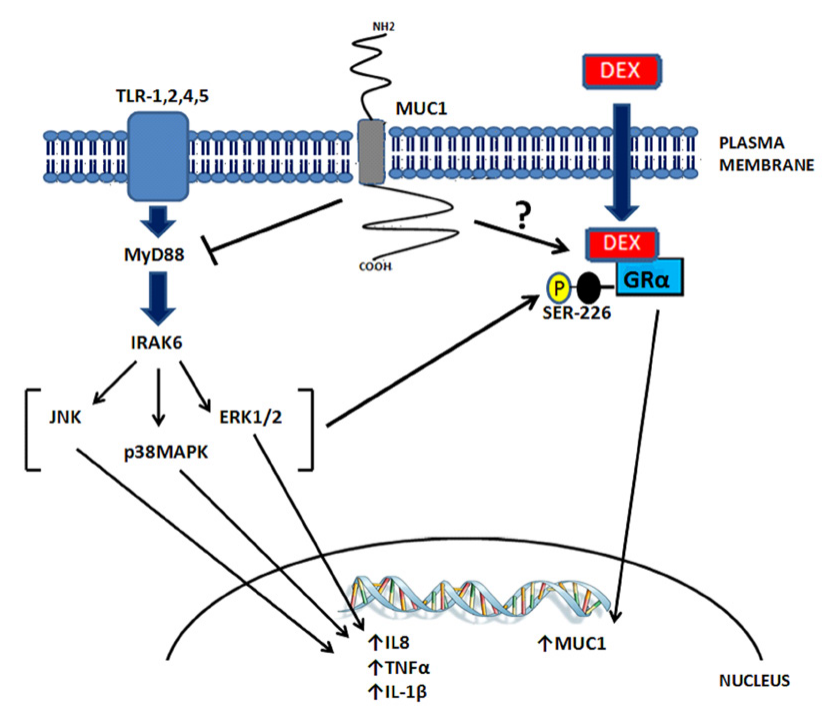

Figure 4: Mechanistic diagram that shows MUC1's anti-inflammatory properties. MUC1 is known to inhibit several toll-like receptors (TLR) through MyD88 recruitment. This results in preventing various downstream signaling cascades, such as c-Jun N-terminal kinase (JNK), p38 mitogen activated map kinase (p38MAPK) and extracellular signal-regulated kinase (ERK1/2), which would lead to the transcription of different pro-inflammatory genes. Dexamethasone (DEX), among other corticosteroids, is known to increase the expression of membrane-tethered MUC1 which would result in increasing its anti-inflammatory capacity. However, corticosteroid receptor (GR) modifications, such as an increased GRa phosphorylation $(P)$ at Ser226, mediated by JNK, p38MAPK and ERK1/2, contributes to steroid resistance by preventing nuclear translocation, thus could have an effect in MUC1 expression. Additionally, the possibility of a potential interaction between MUC1 cytoplasmic tail (MUC1-CT), corticosteroids and their receptors is currently unknown.

function [75-77]. However, up to now, the possibility of a potential interaction between MUC1-CT and corticosteroids and their receptors is unknown. In our opinion, the relevance of studying a potential interaction between mucins, particularly MUC1, and corticosteroids is due to the possibility of providing a mechanistic explanation that would contribute to understand why these drugs are not able to repress inflammation in this particular subset of CRSwNP patients, which are characterized by exhibiting a reduced expression of MUC1.

\section{Conclusion}

This review aims to draw attention to the potential involvement of mucins in corticosteroid mechanisms in CRSwNP, specially focusing in membrane-tethered mucins. We postulate the hypothesis that mucin expression is not a consequence of corticosteroids' actions but a contributor to corticosteroid's mechanisms, thus, should be regarded as a potential mediator in the response to corticosteroids, particularly in CRSwNP. Therefore, future research is required to better address the role of mucins in corticosteroid resistance mechanisms in this disease in order to increase the knowledge regarding the loss of efficacy of corticosteroids in CRSwNP patients. Understanding the corticosteroid resistance mechanisms is crucial in contributing to alleviate and improve the situation of this especially difficult and challenging subset of therapy-resistant CRSwNP patients.

\section{Acknowledgement}

This work was supported by grants SAF2011-26443 (JC), FIS CP11/00293 (JM), CIBERES (CB06/06/0027), ADE10/00020 (Spanish government), FIS
PI11/02618, ACIF/2010/114 (TP) and research grants from Regional Government Prometeo II/2013/014 (JC, JM) 'Generalitat Valenciana'. Support from the CENIT programme (Spanish Government) was obtained.

\section{References}

1. Fokkens WJ, Lund VJ, Mullol J, Bachert C, Alobid I, et al. (2012) EPOS 2012: European position paper on rhinosinusitis and nasal polyps 2012. A summary for otorhinolaryngologists. Rhinology 50: 1-12.

2. Settipane G (1987) Nasal Polyps: Epidemiology, Pathology, Immunology and Treatment. American Journal of Rhinology \& Allergy 1: 119-126.

3. Mygind N, Dahl R, Bachert C (2000) Nasal polyposis, eosinophil dominated inflammation, and allergy. Thorax 55 Suppl 2: S79-83.

4. Van Zele T, Claeys S, Gevaert P, Van Maele G, Holtappels G, et al. (2006) Differentiation of chronic sinus diseases by measurement of inflammatory mediators. Allergy 61: 1280-1289.

5. Polzehl D, Moeller P, Riechelmann H, Perner S (2006) Distinct features of chronic rhinosinusitis with and without nasal polyps. Allergy 61: 1275-1279.

6. Bachert C, Gevaert P, Holtappels G, Cuvelier C, van Cauwenberge P (2000) Nasal polyposis: from cytokines to growth. Am J Rhinol 14: 279-290.

7. Cao PP, Li HB, Wang BF, Wang SB, You XJ, et al. (2009) Distinct immunopathologic characteristics of various types of chronic rhinosinusitis in adult Chinese. J Allergy Clin Immunol 124: 478-484, 484.

8. Zhang N, Holtappels G, Claeys C, Huang G, van Cauwenberge P, et al. (2006) Pattern of inflammation and impact of Staphylococcus aureus enterotoxins in nasal polyps from southern China. Am J Rhinol 20: 445-450.

9. Wen W, Liu W, Zhang L, Bai J, Fan Y, et al. (2012) Increased neutrophilia in nasal polyps reduces the response to oral corticosteroid therapy. J Allergy Clin Immunol 129: 1522-1528.

10. Hew M, Bhavsar P, Torrego A, Meah S, Khorasani N, et al. (2006) Relative corticosteroid insensitivity of peripheral blood mononuclear cells in severe asthma. Am J Respir Crit Care Med 174: 134-141.

11. Pujols L, Fuentes-Prado M, Fernández-Bertolín L, Alobid I, Roca-Ferrer J, et al. (2011) Lower sensitivity of nasal polyp fibroblasts to glucocorticoid antiproliferative effects. Respir Med 105: 218-225

12. Kern RC, Conley DB, Walsh W, Chandra R, Kato A, et al. (2008) Perspectives on the etiology of chronic rhinosinusitis: an immune barrier hypothesis. Am J Rhinol 22: 549-559.

13. Schleimer RP, Kato A, Peters A, Conley D, Kim J, et al. (2009) Epithelium, inflammation, and immunity in the upper airways of humans: studies in chronic rhinosinusitis. Proc Am Thorac Soc 6: 288-294.

14. Rose MC, Voynow JA (2006) Respiratory tract mucin genes and mucin glycoproteins in health and disease. Physiol Rev 86: 245-278.

15. Kim KC (2012) Role of epithelial mucins during airway infection. Pulm Pharmacol Ther 25: 415-419.

16. Hijikata M, Matsushita I, Tanaka G, Tsuchiya T, Ito H, et al. (2011) Molecula cloning of two novel mucin-like genes in the disease-susceptibility locus for diffuse panbronchiolitis. Hum Genet 129: 117-128.

17. Carraway KL, Ramsauer VP, Haq B, Carothers Carraway CA (2003) Cell signaling through membrane mucins. Bioessays 25: 66-71.

18. Ali MS, Pearson JP (2007) Upper airway mucin gene expression: a review. Laryngoscope 117: 932-938.

19. Roy MG1, Livraghi-Butrico A2, Fletcher AA3, McElwee MM4, Evans SE4, et al (2014) Muc5b is required for airway defence. Nature 505: 412-416.

20. Martínez-Antón A, Debolós C, Garrido M, Roca-Ferrer J, Barranco C, et al (2006) Mucin genes have different expression patterns in healthy and diseased upper airway mucosa. Clin Exp Allergy 36: 448-457.

21. Ali MS, Wilson JA, Bennett M, Pearson JP (2005) Mucin gene expression in nasal polyps. Acta Otolaryngol 125: 618-624.

22. Woo HJ, Bae CH, Song SY, Lee HM, Kim YD (2010) Expression of membranebound mucins in human nasal mucosa: different patterns for MUC4 and MUC16. Arch Otolaryngol Head Neck Surg 136: 603-609.

23. Mygind N, Pedersen CB, Prytz S, Sørensen H (1975) Treatment of nasal polyps with intranasal beclomethasone dipropionate aerosol. Clin Allergy 5: 159-164. 
Citation: Peiró T, Milara J, Armengot M, Cortijo J (2014) Mucin Expression and Corticosteroid Efficacy in Chronic Rhinosinusitis with Nasal Polyps. J Steroids Hormon Sci S12: 007. doi:10.4172/2157-7536.S12-007

Page 9 of 10

24. Tos M, Svendstrup F, Arndal H, Orntoft S, Jakobsen J, et al. (1998) Efficacy of an aqueous and a powder formulation of nasal budesonide compared in patients with nasal polyps. Am J Rhinol 12: 183-189.

25. Vendelo Johansen L, Illum P, Kristensen S, Winther L, Vang Petersen S, et al. (1993) The effect of budesonide (Rhinocort) in the treatment of small and medium-sized nasal polyps. Clin Otolaryngol Allied Sci 18: 524-527.

26. Jankowski R, Klossek JM, Attali V, Coste A, Serrano E (2009) Long-term study of fluticasone propionate aqueous nasal spray in acute and maintenance therapy of nasal polyposis. Allergy 64: 944-950.

27. Small CB, Stryszak P, Danzig M, Damiano A (2008) Onset of symptomatic effect of mometasone furoate nasal spray in the treatment of nasal polyposis. $J$ Allergy Clin Immunol 121: 928-932.

28. Dingsor G, Kramer J, Olsholt R, Soderstrom T (1985) Flunisolide nasal spray $0.025 \%$ in the prophylactic treatment of nasal polyposis after polypectomy. A randomized, double blind, parallel, placebo controlled study. Rhinology 23: 4958.

29. Virolainen E, Puhakka H (1980) The effect of intranasal beclomethasone dipropionate on the recurrence of nasal polyps after ethmoidectomy. Rhinology 18: 9-18.

30. Tuncer U, Soylu L, Aydogan B, Karakus F, Akcali C (2003) The effectiveness of steroid treatment in nasal polyposis. Auris Nasus Larynx 30: 263-268.

31. Hissaria P, Smith W, Wormald PJ, Taylor J, Vadas M, et al. (2006) Short course of systemic corticosteroids in sinonasal polyposis: a double-blind, randomized, placebo-controlled trial with evaluation of outcome measures. J Allergy Clin Immunol 118: 128-133.

32. Fernandes AM, Valera FC, Anselmo-Lima WT (2008) Mechanism of action of glucocorticoids in nasal polyposis. Braz J Otorhinolaryngol 74: 279-283.

33. Grzanka A, Misiołek M, Golusiński W, Jarząb J (2011) Molecular mechanisms of glucocorticoids action: implications for treatment of rhinosinusitis and nasal polyposis. Eur Arch Otorhinolaryngol 268: 247-253.

34. Shirasaki H, Watanabe K, Kanaizumi E, Konno N, Sato J, et al. (2004) Expression and localization of steroid receptors in human nasal mucosa. Acta Otolaryngol 124: 958-963.

35. Rhen T, Cidlowski JA (2005) Antiinflammatory action of glucocorticoids--new mechanisms for old drugs. N Engl J Med 353: 1711-1723.

36. Hayashi R, Wada H, Ito K, Adcock IM (2004) Effects of glucocorticoids on gene transcription. Eur J Pharmacol 500: 51-62.

37. Necela BM, Cidlowski JA (2004) Mechanisms of glucocorticoid receptor action in noninflammatory and inflammatory cells. Proc Am Thorac Soc 1: 239-246.

38. Almawi WY, Melemedjian OK (2002) Negative regulation of nuclear factorkappaB activation and function by glucocorticoids. J Mol Endocrinol 28: 69-78.

39. Barnes PJ (2011) Glucocorticosteroids: current and future directions. Br J Pharmacol 163: 29-43.

40. Ito K, Barnes PJ, Adcock IM (2000) Glucocorticoid receptor recruitment of histone deacetylase 2 inhibits interleukin-1beta-induced histone $\mathrm{H} 4$ acetylation on lysines 8 and 12. Mol Cell Biol 20: 6891-6903

41. Barnes PJ (2013) Corticosteroid resistance in patients with asthma and chronic obstructive pulmonary disease. J Allergy Clin Immunol 131: 636-645.

42. Schaaf MJ, Cidlowski JA (2002) Molecular mechanisms of glucocorticoid action and resistance. J Steroid Biochem Mol Biol 83: 37-48.

43. Lewis-Tuffin LJ, Cidlowski JA (2006) The physiology of human glucocorticoid receptor beta (hGRbeta) and glucocorticoid resistance. Ann N Y Acad Sci 1069: 1-9.

44. Adcock IM, Caramori G (2001) Cross-talk between pro-inflammatory transcription factors and glucocorticoids. Immunol Cell Biol 79: 376-384.

45. Pujols L, Mullol J, Torrego A, Picado C (2004) Glucocorticoid receptors in human airways. Allergy 59: 1042-1052.

46. Hamilos DL, Leung DY, Muro S, Kahn AM, Hamilos SS, et al. (2001) GRbeta expression in nasal polyp inflammatory cells and its relationship to the antiinflammatory effects of intranasal fluticasone. J Allergy Clin Immunol 108: 5968.

47. Li P, Li Y, Zhang X, Zhang G, Ye J, et al. (2005) [Detection of glucocorticoid receptor-alpha mRNA expression using FQ-RT-PCR in nasal polyp]. Lin Chuang Er Bi Yan Hou Ke Za Zhi 19: 769-771.

48. Takeno S, Hirakawa K, Ueda T, Furukido K, Osada R, et al. (2002) Nuclear factor-kappa B activation in the nasal polyp epithelium: relationship to local cytokine gene expression. Laryngoscope 112: 53-58.

49. Valera FC, Scrideli C, Queinoz R, Gonzaiga Tone L, Anselmo-Lima WT (2010) NF-kappaB expression predicts clinical outcome for nasal polyposis. Rhinology 48: 408-441.

50. Valera FC, Queiroz R, Scrideli C, Tone LG, Anselmo-Lima WT (2009) Evaluating budesonide efficacy in nasal polyposis and predicting the resistance to treatment. Clin Exp Allergy 39: 81-88.

51. Weigel NL, Moore NL (2007) Steroid receptor phosphorylation: a key modulator of multiple receptor functions. Mol Endocrinol 21: 2311-2319.

52. Barnes PJ (2004) Corticosteroid resistance in airway disease. Proc Am Thorac Soc 1: 264-268.

53. Li LB, Goleva E, Hall CF, Ou LS, Leung DY (2004) Superantigen-induced corticosteroid resistance of human $T$ cells occurs through activation of the mitogen-activated protein kinase kinase/extracellular signal-regulated kinase (MEK-ERK) pathway. J Allergy Clin Immunol 114: 1059-1069.

54. Bendouah Z, Barbeau J, Hamad WA, Desrosiers M (2006) Biofilm formation by Staphylococcus aureus and Pseudomonas aeruginosa is associated with an unfavorable evolution after surgery for chronic sinusitis and nasal polyposis. Otolaryngol Head Neck Surg 134: 991-996.

55. Kai H, Yoshitake K, Hisatsune A, Kido T, Isohama Y, et al. (1996) Dexamethasone suppresses mucus production and MUC-2 and MUC-5AC gene expression by NCl-H292 cells. Am J Physiol 271: L484-488.

56. Lu W, Lillehoj EP, Kim KC (2005) Effects of dexamethasone on Muc5ac mucin production by primary airway goblet cells. Am J Physiol Lung Cell Mol Physiol 288: L52-60.

57. Chen Y, Nickola TJ, DiFronzo NL, Colberg-Poley AM, Rose MC (2006) Dexamethasone-mediated repression of MUC5AC gene expression in human lung epithelial cells. Am J Respir Cell Mol Biol 34: 338-347.

58. Kim YD, Kwon EJ, Park DW, Song SY, Yoon SK, et al. (2002) Interleukin1 beta induces MUC2 and MUC5AC synthesis through cyclooxygenase-2 in $\mathrm{NCl}-\mathrm{H} 292$ cells. Mol Pharmacol 62: 1112-1118.

59. Kim YD, Kwon EJ, Kwon TK, Baek SH, Song SY, et al. (2000) Regulation of IL-1beta-mediated MUC2 gene in NCl-H292 human airway epithelial cells. Biochem Biophys Res Commun 274: 112-116.

60. Treon SP, Mollick JA, Urashima M, Teoh G, Chauhan D, et al. (1999) Muc1 core protein is expressed on multiple myeloma cells and is induced by dexamethasone. Blood 93: 1287-1298.

61. Imai M, Hwang HY, Norris JS, Tomlinson S (2004) The effect of dexamethasone on human mucin 1 expression and antibody-dependent complement sensitivity in a prostate cancer cell line in vitro and in vivo. Immunology 111: 291-297.

62. Seo KY, Chung SH, Lee JH, Park MY, Kim EK (2007) Regulation of membraneassociated mucins in the human corneal epithelial cells by dexamethasone. Cornea 26: 709-714.

63. Bai CH, Song SY, Kim YD (2007) Effect of glucocorticoid on the MUC4 gene in nasal polyps. Laryngoscope 117: 2169-2173.

64. Martinez-Anton A, de Bolos C, Alobid I, Benitez P, Roca-Ferrer J, et al. (2008) Corticosteroid therapy increases membrane-tethered while decreases secreted mucin expression in nasal polyps. Allergy 63: 1368-1376.

65. Peiró T, Frias S, Armengot M, Serrano A, Almudever P, et al. (2012). Mucin expression in nasal polyps of glucocorticoid-resistant patients. 6th European Congress of Pharmacology 17-23.

66. Zrihan-Licht S, Baruch A, Elroy-Stein O, Keydar I, Wreschner DH (1994) Tyrosine phosphorylation of the MUC1 breast cancer membrane proteins. Cytokine receptor-like molecules. FEBS Lett 356: 130-136.

67. Kim KC, Lillehoj EP (2008) MUC1 mucin: a peacemaker in the lung. Am $J$ Respir Cell Mol Biol 39: 644-647.

68. Li Y, Dinwiddie DL, Harrod KS, Jiang Y, Kim KC (2010) Anti-inflammatory effect of MUC1 during respiratory syncytial virus infection of lung epithelial cells in vitro. Am J Physiol Lung Cell Mol Physiol 298: L558-563. 
Citation: Peiró T, Milara J, Armengot M, Cortijo J (2014) Mucin Expression and Corticosteroid Efficacy in Chronic Rhinosinusitis with Nasal Polyps. J Steroids Hormon Sci S12: 007. doi:10.4172/2157-7536.S12-007

Page 10 of 10

69. Ueno K, Koga T, Kato K, Golenbock DT, Gendler SJ, et al. (2008) MUC1 mucin is a negative regulator of toll-like receptor signaling. Am J Respir Cell Mol Biol 38: $263-268$

70. Kyo Y, Kato K, Park YS, Gajghate S, Umehara T, et al. (2012) Antiinflammatory role of MUC1 mucin during infection with nontypeable Haemophilus influenzae. Am J Respir Cell Mol Biol 46: 149-156.

71. Kato K, Lillehoj EP, Park YS, Umehara T, Hoffman NE, et al. (2012) Membranetethered MUC1 mucin is phosphorylated by epidermal growth factor receptor in airway epithelial cells and associates with TLR5 to inhibit recruitment of MyD88. J Immunol 188: 2014-2022.

72. Gendler SJ (2001) MUC1, the renaissance molecule. J Mammary Gland Bio Neoplasia 6: 339-353.

73. Senapati S, Das S, Batra SK (2010) Mucin-interacting proteins: from function to therapeutics. Trends Biochem Sci 35: 236-245.

74. Carson DD (2008) The cytoplasmic tail of MUC1: a very busy place. Sci Signal 1: pe35.

75. Wei X, Xu H, Kufe D (2006) MUC1 oncoprotein stabilizes and activates estrogen receptor alpha. Mol Cell 21: 295-305.

76. Chen YT, Gallup M, Nikulina K, Lazarev S, Zlock L, et al. (2010) Cigarette smoke induces epidermal growth factor receptor-dependent redistribution of apical MUC1 and junctional beta-catenin in polarized human airway epithelial cells. Am J Pathol 177: 1255-1264.

77. Wen Y, Caffrey TC, Wheelock MJ, Johnson KR, Hollingsworth MA (2003) Nuclear association of the cytoplasmic tail of MUC1 and beta-catenin. J Biol Chem 278: 38029-38039.

78. Dorofeyev AE, Vasilenko IV, Rassokhina OA, Kondratiuk RB (2013) Mucosal barrier in ulcerative colitis and Crohn's disease. Gastroenterol Res Pract 2013: 431231.

79. de Bolòs C, Gumà M, Barranco C, Garrido M, Kim YS, et al. (1998) MUC6 expression in breast tissues and cultured cells: abnormal expression in tumors and regulation by steroid hormones. Int J Cancer 77: 193-199.

80. Seong JK, Koo JS, Lee WJ, Kim HN, Park JY, et al. (2002) Upregulation of MUC8 and downregulation of MUC5AC by inflammatory mediators in human nasal polyps and cultured nasal epithelium. Acta Otolaryngol 122: 401-407.

81. Kim CH, Kim HJ, Song KS, Seong JK, Kim KS, et al. (2005) MUC8 as a ciliated cell marker in human nasal epithelium. Acta Otolaryngol 125: 76-81.

82. Ishinaga H, Takeuchi K, Kishioka C, Yagawa M, Majima Y (2002) Effects of dexamethasone on mucin gene expression in cultured human nasal epithelial cells. Laryngoscope 112: 1436-1440.

83. Maines-Bandiera S, Woo MM, Borugian M, Molday LL, Hii T, et al. (2010) Oviductal glycoprotein (OVGP1, MUC9): a differentiation-based mucin present in serum of women with ovarian cancer. Int J Gynecol Cancer 20: 16-22.

84. Maher DM, Gupta BK, Nagata S, Jaggi M, Chauhan SC (2011) Mucin 13: structure, function, and potential roles in cancer pathogenesis. Mol Cancer Res 9: 531-537.

85. Gupta BK, Maher DM, Ebeling MC, Stephenson PD, Puumala SE, et al. (2013) Functions and regulation of MUC13 mucin in colon cancer cells. J Gastroenterol.

86. Pallesen LT, Berglund L, Rasmussen LK, Petersen TE, Rasmussen JT (2002) Isolation and characterization of MUC15, a novel cell membrane-associated mucin. Eur J Biochem 269: 2755-2763.
87. Wang RY, Chen L, Chen HY, Hu L, Li L, et al. (2013) MUC15 inhibits dimerization of EGFR and PI3K-AKT signaling and is associated with aggressive hepatocellular carcinomas in patients. Gastroenterology 145: 14361448.

88. Nam KH, Noh TW, Chung SH, Lee SH, Lee MK, et al. (2011) Expression of the membrane mucins MUC4 and MUC15, potential markers of malignancy and prognosis, in papillary thyroid carcinoma. Thyroid 21: 745-750.

89. Resta-Lenert S, Das S, Batra SK, Ho SB (2011) Muc17 protects intestinal epithelial cells from enteroinvasive $\mathrm{E}$. coli infection by promoting epithelial barrier integrity. Am J Physiol Gastrointest Liver Physiol 300: G1144-1155.

90. Gum JR Jr, Crawley SC, Hicks JW, Szymkowski DE, Kim YS (2002) MUC17, a novel membrane-tethered mucin. Biochem Biophys Res Commun 291: 466475 .

91. Kitamoto S, Yokoyama S, Higashi M, Yamada N, Matsubara S, et al. (2012) Expression of MUC17 is regulated by HIF1 $\hat{I} \pm$-mediated hypoxic responses and requires a methylation-free hypoxia responsible element in pancreatic cancer PLoS One 7: e44108.

92. Zeng GF, Cai SX, Wu GJ (2011) Up-regulation of METCAM/MUC18 promotes motility, invasion, and tumorigenesis of human breast cancer cells. BMC Cancer 11: 113.

93. Mobley AK, Braeuer RR, Kamiya T, Shoshan E, Bar-Eli M (2012) Driving transcriptional regulators in melanoma metastasis. Cancer Metastasis Rev 31: 621-632.

94. Wu Q, Case SR, Minor MN, Jiang D, Martin RJ, et al. (2013) A novel function of MUC18: amplification of lung inflammation during bacterial infection. Am J Pathol 182: 819-827.

95. Simon GC, Martin RJ, Smith S, Thaikoottathil J, Bowler RP, et al. (2011) Upregulation of MUC18 in airway epithelial cells by IL-13: implications in bacterial adherence. Am J Respir Cell Mol Biol 44: 606-613.

96. Higuchi T, Orita T, Nakanishi S, Katsuya K, Watanabe H, et al. (2004) Molecular cloning, genomic structure, and expression analysis of MUC20, a novel mucin protein, up-regulated in injured kidney. J Biol Chem 279: 1968-1979.

97. Yi Y, Kamata-Sakurai M, Denda-Nagai K, Itoh T, Okada K, et al. (2010) Mucin 21/epiglycanin modulates cell adhesion. J Biol Chem 285: 21233-21240.

98. Bafna S, Kaur S, Batra SK (2010) Membrane-bound mucins: the mechanistic basis for alterations in the growth and survival of cancer cells. Oncogene 29: 2893-2904.

99. Constantinou PE, Danysh BP, Dharmaraj N, Carson DD (2011) Transmembrane mucins as novel therapeutic targets. Expert Rev Endocrinol Metab 6: 835-848.
This article was originally published in a special issue, Steroid Hormone Metabolism handled by Editor. Dr. Carin Wittnich, University of Toronto, Canada 